\title{
Analisis Kesulitan Siswa Menyelesaikan Soal Matematika Materi Vektor Kelas X SMA Terpadu Wira Bhakti
}

\author{
Surialin $^{1}$, Sarson W. Pomalato², Tedy Machmud ${ }^{3}$ \\ 1,2,3Jurusan Matematika, Fakultas MIPA Universitas Negeri Gorontalo \\ E-mail: surialinmat@gmail.com
}

\begin{abstract}
Abstrak:Penelitian ini dilaksanakan di SMA Terpadu Wira Bhakti Gorontalo tahun ajaran 2020/2021 dengan tujuan untuk menganalisi dan mendeskripsikan kesulitan siswa serta faktor apa saja penyebab kesulitan siswa dalam menyelesaikan soal matematika pada materi vektor. Metode penelitian yang digunakan dalam penelitian ini adalah deskriptif analitis dengan bentuk studi kasus dimana peneliti meneliti secara intensif tentang kesulitan menyelesikan soal matematika pada materi vektor. Hasil dari penelitian ini menunjukan bahwa dalam menyelesaikan soal matematika pada materi vektor, siswa masi mengalami kesulitan dalam; (a) Penerapan fakta, (b) Penerpan Konsep, (c) Penerapan prinsip dan (d) Penerpan Operasi. Kesulitan ini dialami oleh siswa dari semua tingkat kemampuan. Faktor penyebab dari kesulitan diatas adalah; (a) tidak mampu menggali informasi yang ada dalam soal, (b) tidak mampu merubah suatu model matematika kedalam model lain, (c) salah dalam menggunakan rumus.
\end{abstract}

Kata Kunci: Analisis kesulitan menyelesaikan soal: Vektor

Abstract: This descriptive analysis case study was conducted at SMA Terpadu Wira Bhakti Gorontalo 2020/2021 to analyze and describe the student's difficulty and its causative factors in solving mathematics questions. The researcher intensively studies the vector topic. The findings revealed the students experienced problems in the following implementations: (a) Fact, (b) Concept, (c) Principle, and (d) Operation, all experienced by students in every level of skills. Meanwhile, the causative factors are as follows; (a) the inability to retrieve information in the questions, (b) the inability to alter a mathematic model into another model, (c) misuse of formulas.

Keywords: Analysis of Difficulty in solving problems: Vector

\section{PENDAHULUAN}

Pendidikan sebagai wadah dalam pengembangan kemampuan dan potensi diri bagi peserta didik, karena setiap perkembangan zaman dan perubahan teknologi yang terjadi saat ini pasti dapat dirasahkan dan dialami oleh setiap manusia, oleh karena itu selain dari pihak pemerintah, pihak sekolah, peserta didik pun juga harus bersiap diri dalam upaya meningkatkan kualitas pendidikan. Dalam upaya meningkatkan kualitas pendidikan dan sumber daya manusia (SDM), Pemerintah telah mengadakan program wajib belajar 12 tahun. Dimana setiap warga Negara berhak menerima pendiddikan dari usia dini sampai kejenjang menengah atas. Dalam melaksanakan program tersebut peserta didik diwajibkan menempuh mata pelajaran wajib, salah satunya adalah pelajaran matematika. 
Tujuan pemebelajan matematika di Indonesia secara kongkrit tertuang dalam kurikulum 2013 bahwa pembelajaran matematika mengharapkan agar siswa mampu memahami konsep matematika, menjelaskan keterkaitan antar konsep dan mengaplikasikan konsep atau algoritma, secara luwes, akurat, efisien, dan tepat, dalam pemecahan masalah; Menggunakan penalaran pada pola dan sifat, melakukan manipulasi matematika dalam membuat generalisasi, menyusun bukti, atau menjelaskan gagasan dan pernyataan matematika; Mengungkapkan simbol matematika secara lisan maupun tulisan, mampu mengaplikasikan matematika dalam kehidupan sehari-hari dan mampu menyelesaikan permasalahan matematika.

Menurut Abdurrahman (2012: 225) matematika ialah bahasa simbol guna mengekspresikan hubungan - hubungan kuantitatif dan keruangan, yang memudahkan manusia berpikir dalam memecahkan masalah sehari-hari. Matematika dapat digunakan dalam menyelesaikan berbagai masalah. Tetapi di lain sisi matematika dianggap sebagai mata pelajaran yang sulit bagi siswa.

kesulitan belajar merupkan suatu keadaan yang bersifat heterogen, yang terwujud dalam bentuk kesulitan belajar di satu atau lebih fungsi-fungsi psikologis secara mendasar. Terdapat banyak siswa yang masih mengalami kesulitan. Kesulitan tersebut, yaitu dalam hal menerapkan rumus-rumus matematika, kekeliruan dalam menerjemahkan konsep dan memahami bahasa matematika (Jamaris.2014: 10)

Saat ini, dalam banyak kasus baik dipertontonkan dimedia maupun keluhan beberapa siswa, fenomena saat ini dalam pembelajaran matematika, masih banyak siswa yang menganggap pembelajaran matematika sebagai momok yang menakutkan. hal ini disebabkan oleh beberapa faktor baik dari guru mata pelajaran maupun dari siswa sendiri sehingga berdampak pada kurangnya Pemahaman siswa terhadap materi-materi yang diajarkan, siswa mengalami kesulitan dalam menyelesaikan soal-soal matematika yang diberikan dan berdampak hasil belajar siswa yang tidak memuaskan pada mata pelajaran matematika.

Sesuai dengan observasi awal yang dilakukan oleh peneliti lakukan di SMA Terpadu Wira Bhakti dijumpai banyaknya siswa yang masih mengalami kesulitan dalam menyelesaikan soal matematika. Hal ini ditunjukan dengan banyaknya kesalahan yang dilakukan oleh siswa dalam meneyelesaikan soal matematika yang diberikan oleh guru mata pelajaran. Peneliti juga melakukan wawancara dengan guru mata pelajaran disekolah tersebut dan mendapatkan keterangan bahwa masih banyak siswa yang melakukan kesalahan dalam meyelesaikan soal yang sedikit dimodifikasi dari contoh soal yang diberikan pada saat proses pembelajaran berlangsung. Hal ini menunjukan bahwa siswa masih mengalami kesulitan dalam menyelesaikan soal matematika yang diberikan oleh guru mata pelajaran.

Dari permasalahan diatas maka dipandang perlu mengadakan suatu bentuk penelitian untuk menggali akar permasalahan yang dialami siswa di SMA Terpadu Wira Bhakti. 
Penelitian serupa yang telah dilakukan oleh Aziz Dkk (2009) tentang kesulitan siswa dalam menyelesaikan soal cerita, Penelitian Nur Queen (2018) tentang analisis kesalahan siswa dalam menyelesaikan soal matematika. kesulitan yang sering dialami oleh siswa dalam menyelesaikan soal-soal matematika terjadi pada objek konsep, fakta, prinsip dan prosedur.

Adapun yang menjadi tujuan dari penelitian yaitu untuk menganalisis dan mendeskripsikan kesulitan siswa dalam menyeleaikan soal matematika serta menganalisis dan mendeskripsikan faktor penyebab kesulitan siswa dalam menyeleaikan soal matematika pada materi vector, sub bab: panjang vektor, jarak dua titik, dan vektor satuan di kelas X SMA Terpadu Wira Bhakti.

\section{METODE}

Dalam penelitian ini, Metode yang digunakan adalah deskriptif analitis dengan bentuk studi kasus. Dalam hal ini memfokuskan secara intensif pada objek tertentu, dengan mempelajarinya sebagai kasus Nawawi dalam Puspitasari (1990:72).

Instrumen yang digunakan dalam penelitian ini berupa tes hasil belajar dan pedoman wawancara.

Tes hasil belajara yang digunakan yaitu tes bentuk esai yang telah diuji validitasnya terlebih dahulu dengan tujuan untuk memperoleh data tentang kesulitan siswa dalam menyelesaikan soal matematika pada materi vektor. Dan metode wawancara digunakan untuk menggali informasi tentang kesulitan dan faktor-faktor penyebab siswa dalam menyelesaikan soal matematika pada materi Vektor. Proses wawancara dalam penelitian ini dilakukan secara langsung dengan siswa dan guru mata pelajaran.

\section{HASIL DAN PEMBAHASAN}

Setelah memberikan tes hasil belajar, langkah selanjutnya yang dilakukan oleh peneliti yaitu memeriksa jawaban para siswa. Dari jawaban para siswa, peneliti dapat mengetahui kesulitankesulitan yang dialami oleh siswa hal ini dapat dilihat dari kesalahan-kealahan atau langkahlangkah yang tidak seharusnya dilakukan oleh siswa dalam menyelesaikan soal pada materi vektor

Dari hasil perolehan siswa setelah mengerjkan tes hasil belajar selanjutnya peneliti mengelompokan tingkat kemampuan siswa berdasarkan nilai KKM yang ada di kelas X yaitu 75 dengan rentang nilai sebagai berikut:

- Siswa dengan kategori kemampuan tinggi dengan rentang nilai 85 - 100

- Siswa dengan kategori kemampuan sedang dengan rentang nilai 65-84

- Siswa dengan kategori kemampuan rendah dengan rentang nilai kurang dari 65 
Berikut tabel rekapitulasi keseluruhan nilai siswa berdasarkan tingkat kemampuan siswa.

Tabel 1. Rekapan keseluruhan nilai siswa berdasarkan tingkat kemampuan matematika

\begin{tabular}{ccc}
\hline Tingkat Kemampuan & \multicolumn{1}{c}{ Rentang Nilai } & Jumlah Siswa \\
\hline Tinggi & $85-100$ & 3 \\
Sedang & $65-84$ & 23 \\
Rendah & $0-64$ & 5
\end{tabular}

Berdasarkan tabel diatas, diproleh data bahwa dari 31 siswa di kelas X(satu) terdapat 5 siswa dengan kemampuan rendah, 23 siswa dengan kemampuan sedang dan 3 siswa dengan kemampuan tinggi.

Untuk lebih mudah dalam membandingkan banyaknya siswa yang mengalami kesulitan dan letak kesalahan yang satu dengan lainnya pada masing-masing butir soal, maka peneliti merangkum kesulitan dan letak kesalahan tersebut dalam bentuk tabel.

Tabel 2. Presentasi siswa yang mengalami kesulitanpada tiap butir soal

\begin{tabular}{cccc}
\hline No. Soal & Benar Sempurna & Tidak Menjawab & Siswa Mengalami Kesulitan \\
\hline 1 & $64,52 \%$ & $0 \%$ & $35,48 \%$ \\
2 & $32,26 \%$ & $4,41 \%$ & $67,74 \%$ \\
3 & $45,16 \%$ & $3,23 \%$ & $54,84 \%$ \\
4 & $19,35 \%$ & $0 \%$ & $80,65 \%$ \\
5 & $45,16 \%$ & $6,46 \%$ & $54,84 \%$ \\
7 & $29,03 \%$ & $9,68 \%$ & $70,97 \%$ \\
8 & $38,71 \%$ & $9,68 \%$ & $61,29 \%$ \\
9 & $61,30 \%$ & $0 \%$ & $38,70 \%$ \\
10 & $29,03 \%$ & $0 \%$ & $70,97 \%$ \\
Rata-rata & $22,58 \%$ & $6,4 \%$ & $77,42 \%$ \\
\hline
\end{tabular}

Berdasarkan tabel diatas, dapat dilihat bahwa dalam mengerjakan soal metematika khususnya pada materi vektor diperoleh rata-rata siswa yang menjawab sempurna sebesar $38,71 \%$, rata-rata siswa yang tidak menjawab sebesar 3,98\%, dan rata-rata siswa yang mengalami kesulitan sebesar $61,29 \%$ dari 10 nomor soal yang dikerjakan. 
Tabel 3. Presentasi kesulitan siswa pada tiap nomor soal berdasarkan objek matematika

\begin{tabular}{ccccc}
\hline \multirow{2}{*}{ No Soal } & \multicolumn{4}{c}{ Jenis kesulitan (\%) } \\
\cline { 2 - 5 } & Fakta & Konsep & Prinsip & Operasi \\
\hline 1 & $3,23 \%$ & $32,25 \%$ & $19,35 \%$ & $0 \%$ \\
2 & $61,3 \%$ & $0 \%$ & $0 \%$ & $0 \%$ \\
3 & $9,67 \%$ & $51,6 \%$ & $25,8 \%$ & $16,13 \%$ \\
4 & $0 \%$ & $0 \%$ & $64,51 \%$ & $22,58 \%$ \\
5 & $6,13 \%$ & $35,48 \%$ & $22,58 \%$ & $16,13 \%$ \\
6 & $9,35 \%$ & $41,93 \%$ & $16,12 \%$ & $0 \%$ \\
7 & $0 \%$ & $0 \%$ & $29,03 \%$ & $2,58 \%$ \\
8 & $0 \%$ & $22,58 \%$ & $12,9 \%$ & $16,13 \%$ \\
9 & $5,80 \%$ & $67,74 \%$ & $22,58 \%$ & $19,35 \%$ \\
10 & $0 \%$ & $54,84 \%$ & $29,03 \%$ & $16,13 \%$ \\
Rata-rata & $3,55 \%$ & $38 \%$ & $24,19 \%$ & $10,90 \%$ \\
\hline
\end{tabular}

Berdasarkan tabel diatas, dapat dilihat bahwa siswa kelas x SMA terpadu wira bhakti gorontalo masih mengalami kesulitan dalam menyelesaikan soal matematika khususnya pada materi Vektor dengan presentasi kesulitan sbb; (a) pada penerapan fakta sebesar 13,55\%, (b) pada penerapan konsep sebesar 38\%, (c) pada penerapan prinsip sebesar 24,19\% dan (d) pada penerapan operasi sebesar $10,90 \%$

Berikut adalah contoh-contoh kasus kesulitan siswa dalam menyelesaikan soal berdasarkan objek matematika.

1. Objek Fakta

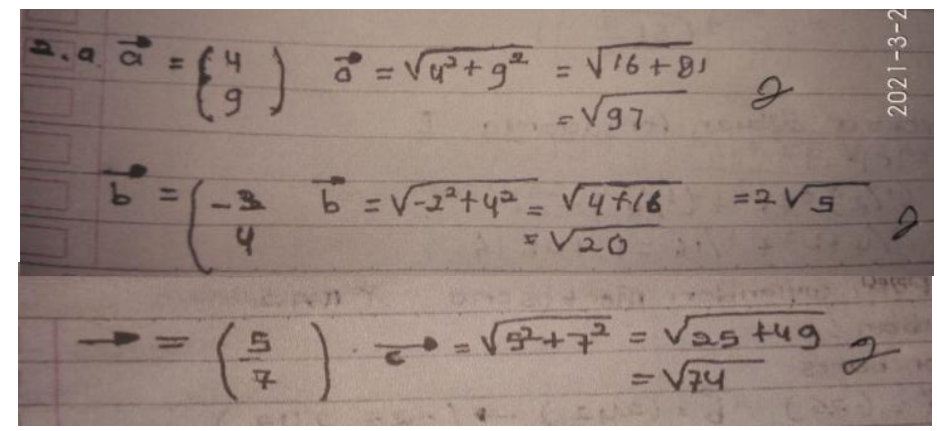

Gambar 1. Contoh kesulitan fakta pada soal nomor 2 
Pada tahap penerapan fakta, dari 10 nomor soal yang dijadikan instrumen dalam penelitian ini, siswa mengalami kesulitan tertinggi pada soal nomor 2 yaitu sebanyak $61,3 \%$ dari 31 siswa yang mengikuti tes hasil belajar. Kesulitan ini terjadi dalam hal menuliskan simbol panjang fektor.

2. Objek konsep

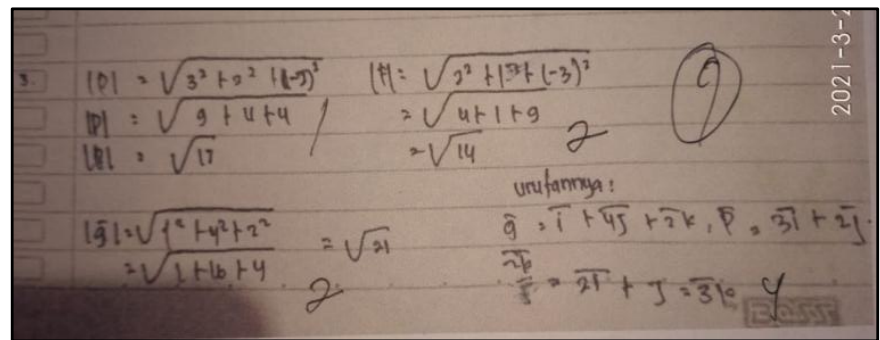

Gambar 2. Contoh kesulitan dalam penerpan konsep

Pada tahapan penerapan konsep, siswa mengalami kesilitan tertinggi pada soal nomor 9 yaitu sebanyak 67,74\% dari 31 siswa yang mengikuti tes hasil belajar. Wujut kesulitan ini terjadi dalam hal memahami maksud dari soal dan penentuan rumus yang akan digunakan.

3. Objek prinsip

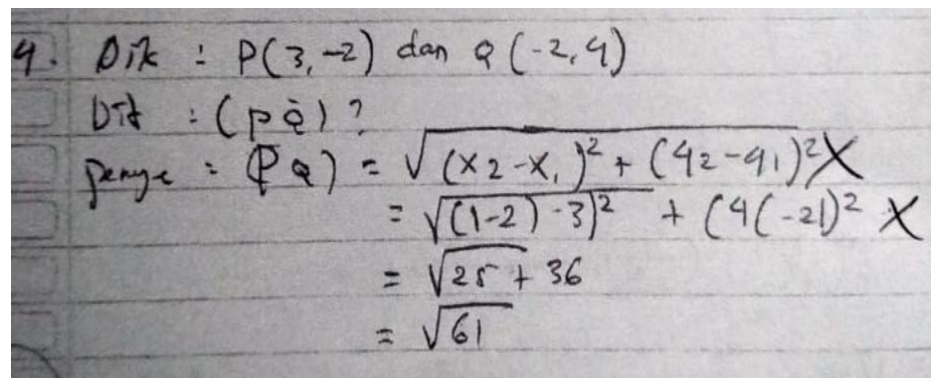

Gambar 3. Contoh kesulitan prinsip

Pada tahapan penerapan prinsip, siswa mengalami kesilitan tertinggi pada soal nomor 4 yaitu sebanyak $64,51 \%$ dari 31 siswa yang mengikuti tes hasil belajar. Wujut kesulitan ini yaitu dalam hal menyalin data dari soal dan dalam hal penggunaan rumus.

4. Objek operasi

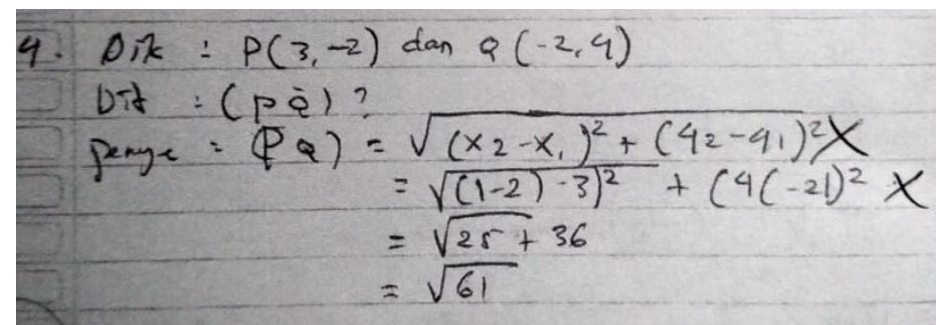

Gambar 4. contoh kesulitan operasi

Pada tahapan penerapan prinsip, siswa mengalami kesilitan tertinggi pada soal nomor 4 yaitu sebanyak 22,58\% dari 31 siswa yang mengikuti tes hasil belajar. Wujud kesulitan ini yaitu dalam hal melakukan operasi aljabar. 
Dari hasil wawancara terhadap kelima (5) subjek yang dijadikan sebagai respondendalam penelitian ini, ternyata siswa mengalami kesulitan dalam penerapan fakta, konsep, prinsip dan operasi baik dari siswa degan kategori kemampuan tinggi, sedang maupun rendah. Kesulitankesulitan ini tidak hanya dialami oleh siswa yang dijadikan sebagai responden dalam penelitian ini namun kesulitan-kesulitan ini dialami oleh hapir semua siswa yang tidak dijadikan sebagai responden dalam penelitian ini. Dari sepuluh nomor soal yang dijadikan instrument dalam penelitian ini, siswa mengalami kesulitan dalam penerapan fakta, konsep, prinsip dan operasi. Namun kesulitan yang lebih menonjol yang dialami oleh siswa adalah dalam hala penerapan konsep dengan rata-rata $38 \%$.

Kesulitan-kesulitan diatas tidak terjadi begitu saja. Akan tetapi ada indikator-indikator yang menjadi penyebab terjadinya kesulitan-kesulitan diatas. Baik yang berasal dari dalam diri siswa (internal), maupun yang bersumber dari lingkungan sekolah dan lingkungan keluarga (eksternal). Fakor yang bersumber dari dalam diri siswa daiantaranya kurangnya minat siswa terhadap materi pelajaran, siswa kurang latihan mengerjakan soal-soal metematika, siswa kurang mengulangi mari pelajran yang diberikan oleh guru saat diluar jam pelajaran, dan siswa takut bertaya baik kepada guru mata pelajaran maupun teman sekelas apabila ada materi yang belum dimengerti. Sedangkan faktor yang bersunber dari luar diri siswa dalam hal ini faktor lingkungan belajar dan lingkungan keluarga diantaranya cara mengajar guru yang cepat sehingga terkadang siswa kurang memahami apa yang dijelaskan oleh guru sehingga siswa tertinggal pada materi tersebut, kurang memberikan tugas kepada siswa sebagai penguatan terhadap materi yang telah diajarkan dan kurangnya motifasi yang diberikan ole orang tua kepada siswa untuk belajar dalam hal ini orangtua acuh tak acuh kepada siswa.

\section{SIMPULAN DAN SARAN}

Simpulan dari penelitian ini menggambarkan bahwa letak kesulitan siswa dalam menyelesaikan soal matematika pada materi vektor yaitu pada penerapan fakta dengan rata-rata 13,55\%, penerapan konsep dengan rata-rata 38\%, penerapan prinsip 24,19\% dan penerapan operasi/prosedur dengan rata-rata 10,90\%. Dari hasil analisis data bahwa faktor-faktor yang menyebabkan kesulitan siswa pada penerapan fakta yaitu siswa tidak menulisakan simbol vektor dan panjang vektor, untuk penerapan konsep siswa tidak mampu menggali informasi yang ada dalam soal, salah dalam penentuan rumus yang akan digunakan. Untuk penerpan prinsip yaitu siswa tidak mampu menggali informasi yang ada dalam soal, siswa tidak mampu merubaha suatu model matematika kedalam model lainya, siswa salah dalam menggunakan rumus. Sedangkan untuk penerapan operasi/prosedur yaitu siswa cenderung mempersingkat jawaban sehingga berdampak pada kesalahan dalam menuliskan jawaban akhir dari soal. 
Faktor lain yang menjadi penyebab kesulitan siswa dalam menyelesaikan soal-soal matematika adalah lingkungan sekolah dan lingkungan keluarga (eksternal). Diantaranya cara mengajar guru yang terlalu cepat sehingga menyebabkan siswa ketinggalan dalam memahami materi yang diajarkan oleh guru, siswa takut bertanya kepada guru ataupun teman sekelas apabila ada materi yang tidak dipahami, kurangya tugas yang diberikan kepada siswa sebagai bentuk pendalam terhadap materi yang dipelajari pada saat proses belajar mengajar dan kuranngya dukungan atau motifasi orang tua kepada siswa untuk belajar ketika diluar jam pelajaran diskolah.

Saran bagi siswa, dalam proses pemebalajaran sebaiknya siswa tidak usah takut untuk bertanya kepada guru atau teman sekelas apabila ada materi yang belum dimengerti, dalam mengerjakan soal siswa sebaiknya tidak terburu dan mengecek kembali jawaban yang telah dikerjakan dan siswa juga sebaiknya lebih banyak mengulangi atau mengerjakan soal-soal matematika agar terbiasa dalam mengerjakan soal. Bagi peneliti selanjutnya, Dalam penelitian ini tidak dilakukan pengulangan untuk kesalahan yang dilakukan oleh siswa, sebaiknya pada peneliti selanjutya dilakukan pengulangan sehingga siswa lebih paham terhadap letak kesalahan yang dilakukan dan dapat membantu siswa dalam mengatasi kesulitan yang dialami oleh siswa dalam mengerjakan soal metematika.

\section{DAFTAR PUSTAKA}

Purwanto agus erwan. (2007). Metode penelitian kuantitatif (untuk admistrasi publik dan masalah-masalah sosial). Yogyakarta: gava media

Echy Puspitasari, Edy Y, Asep N. (2015). Analisis kesulitan siswa menyelesaikan soal cerita materi sistem persamaan linear dua variabel di smp. Program Studi Pendidikan Matematika FKIP UNTAN. Pontianak: Tidak diterbitkan

azis. (2019). Analisis Kesulitan Siswa Dalam Menyelesaikan Soal Cerita Pada Pembelajaran Matematika Kelas VIII. Jurnal Akademik Pendidikan Matematika FKIP Unidayan, Volume 5 - Nomor 1, Mei 2019

Jamaris, Martini. (2014). Kesulitan belajar perspektif, assessmen, dan penanggulangannya. Bogor: Galia indonesia

Abdurahman, Mulyono. (2012). Pendidikan bagi anak berkesulitan belajar. Jakarta: PT Rineka cipta

Marpaung, Radiat, Nur Queen. 2018. Analisis kesalahan siswa dalam menyelesaikan soal matematika di mts swasta aisyiyah sumatera utara. program studi pendidikan matematika fakultas ilmu tarbiyah dan keguruan universitas islam negeri sumatera utara: Medan 
Purwanto agus erwan. 2007. Metode penelitian kuantitatif (untuk admistrasi publik dan masalahmasalah sosial). Yogyakarta: gava media

Sugiyono. 2013. Metode Penelitian Kombinasi (Mixed Methods). Bandung: AlfaBeta

Sugiyono. 2014. Metode Penelitian Pendidikan (Pendekatan Kuantitatif, Kualitatif, dan R\&D). Bandung: Alfabeta 